Arch. Dis. Childh., 1969, 44, 435.

\title{
Insulinoma in Childhood
}

\author{
JILLIAN R. MANN, P. H. W. RAYNER, and A. GOUREVITCH \\ From the Children's Hospital, Birmingham
}

Hypoglycaemia is an important cause of cerebral damage in childhood. While much attention has recently been directed to its detection and treatment in the neonatal period, in later childhood the diagnosis is often delayed. There are many possible causes of hypoglycaemia in childhood, but in only a minority of cases is a precise diagnosis made, the majority being labelled 'idiopathic'. An insulin-secreting islet cell adenoma of the pancreas (insulinoma) is a rare cause of childhood hypoglycaemia; Drash and Schultz (1967) found fewer than 30 cases in their review. The case of a 12-year-old girl with an insulinoma is described in this paper. In an attempt to establish the incidence of the condition in the United Kingdom, the heads of undergraduate and postgraduate Paediatric Departments were asked if any cases of insulinoma had been encountered by them during the previous 10 years. 4 cases were reported to us and brief details of these patients are also presented.

In the adult the incidence of insulinoma is higher and the diagnostic criteria more clearly defined than in childhood. Our experience and that of others (Drash and Schultz, 1967; Floyd et $a l ., 1964)$ suggests that diagnostic procedures, such as the tolbutamide test, are frequently unhelpful in childhood. The diagnosis and treatment of the condition in childhood is discussed.

\section{Case History}

Christine H. was first seen in July 1966 at $11 \frac{1}{2}$ years of age with a 1-month history of attacks during which she stared vacantly or became unsteady on her feet for a few seconds. On the day of admission she had a generalized convulsion which was preceded by giddiness and nausea. No abnormal physical signs were found. Investigations revealed fasting whole blood sugar $54 \mathrm{mg}$./100 ml., serum calcium $9.5 \mathrm{mg}$. $/ 100 \mathrm{ml}$., serum phosphorus $4.5 \mathrm{mg} . / 100 \mathrm{ml}$., serum alkaline phosphatase $32 \mathrm{KA}$ units. Skull $x$-ray was normal. An EEG was abnormal and suggestive of centrencephalic epilepsy. A diagnosis of idiopathic epilepsy was made and anticonvulsant therapy started. Despite a variety of drugs which included phenytoin, ethosuximide,

Received December 13, 1968. sulthiame, and primidone, she continued to have generalized convulsions approximately twice weekly, frequently in the early morning. She attended a junior school where she was noted at times to appear tired and drowsy.

In July 1967, at the age of $12 \frac{1}{2}$ years, she was again admitted to hospital. On the day before admission she had been unusually drowsy, and the following morning she was completely unrousable. On examination she was in deep coma, responding only to painful stimuli. She was flushed and sweating, pulse $135 / \mathrm{min}$. Blood pressure $110 / 80 \mathrm{~mm}$. Hg. There were no other abnormal physical signs. Height $144 \cdot 8 \mathrm{~cm}$., weight $35 \cdot 8 \mathrm{~kg}$., early pubertal development present. She is the third child in a family of 7. She was born by vertex delivery at term, birthweight 2947 g. $\left(6 \frac{1}{2} \mathrm{lb}\right.$.). An exchange transfusion had been performed after birth for Rhesus incompatibility. A younger brother had 'febrile' convulsions until 4 years of age, and one cousin developed diabetes mellitus in childhood.

Initial investigations and treatment. The history and physical findings suggested hypoglycaemic coma. Initial investigations gave the following results: blood sugar $28 \mathrm{mg} . / 100 \mathrm{ml}$., CSF sugar $23 \mathrm{mg} . / 100 \mathrm{ml}$., CSF protein $40 \mathrm{mg} . / 100 \mathrm{ml}$. Plasma electrolytes, urea, calcium, and phosphorus were normal, but the plasma alkaline phosphatase was $60 \mathrm{KA}$ units. Serum salicylate $1.4 \mathrm{mg} . / 100 \mathrm{ml}$., and plasma proteins and transaminases were normal. The skull and chest $x$-rays were normal, and the skeletal maturation was assessed as 13 years (Greulich and Pyle). An EEG revealed slow activity of high amplitude bilaterally.

The hypoglycaemia was controlled with difficulty; intravenous dextrose $10 \mathrm{~g}$. (as $50 \%$ solution) and hydrocortisone $100 \mathrm{mg}$. were given, after which the blood sugar rose to $66 \mathrm{mg} . / 100 \mathrm{ml}$. Glucagon $1 \mathrm{mg}$. was given, and normoglycaemia was maintained with an intravenous infusion of dextrose $10 \%$ and hydrocortisone, together with dextrose feeds via an intragastric tube. Restoration of the blood sugar to normal produced no immediate change in her conscious level which improved slowly during the subsequent 2 days. Corticosteroid therapy was discontinued after 4 days. A period of extreme restlessness and aphasia followed and a left hemiparesis was present. During the following 3 weeks her speech improved, though remaining slurred, and she became able to walk with support. 
TABLE I

Plasma Insulin and Blood Sugar Levels

\begin{tabular}{|c|c|c|}
\hline $\begin{array}{l}\text { Plasma } \\
\text { Insulin } \\
(\mu \mathrm{U} / \mathrm{ml} .)\end{array}$ & $\begin{array}{c}\text { Blood } \\
\text { Sugar } \\
(\mathrm{mg} . / 100 \mathrm{ml} .)\end{array}$ & Comment \\
\hline & $\begin{array}{l}28 \\
32\end{array}$ & $\begin{array}{l}\text { On admission before treatment } \\
\text { After intravenous dextrose }\end{array}$ \\
\hline 196 & 66 & $\begin{array}{l}\text { After intravenous dextrose and } \\
\text { hydrocortisone }\end{array}$ \\
\hline 213 & 134 & $\begin{array}{l}\text { After 3-hour fast, while on oral } \\
\text { steroids }\end{array}$ \\
\hline 91 & 112 & After 8-hour fast \\
\hline 85 & 52 & After 10 -hour fast \\
\hline 120 & 一 & After 10 -hour fast \\
\hline 98 & 148 & Fasting, day of operation \\
\hline 91 & 160 & During operation \\
\hline 49 & 148 & Immediately after operation \\
\hline 10 & - & Fasting, 1 day after operation \\
\hline 30 & 一 & Fasting, 4 days after operation \\
\hline 9 & 一 & Fasting, 4 weeks after operation \\
\hline 22 & 一 & Fasting, 6 weeks after operation \\
\hline
\end{tabular}

Further investigations and treatment. A provisional diagnosis of insulinoma was made on the basis of the severity of the initial hypoglycaemia, and the lack of evidence of other potential causes in this agegroup such as poisoning, pituitary or adrenal disease, liver disease, and diabetes. This was supported by plasma insulin determinations which were performed on a number of occasions, consistently raised random and fasting levels being obtained (Table I). (The upper

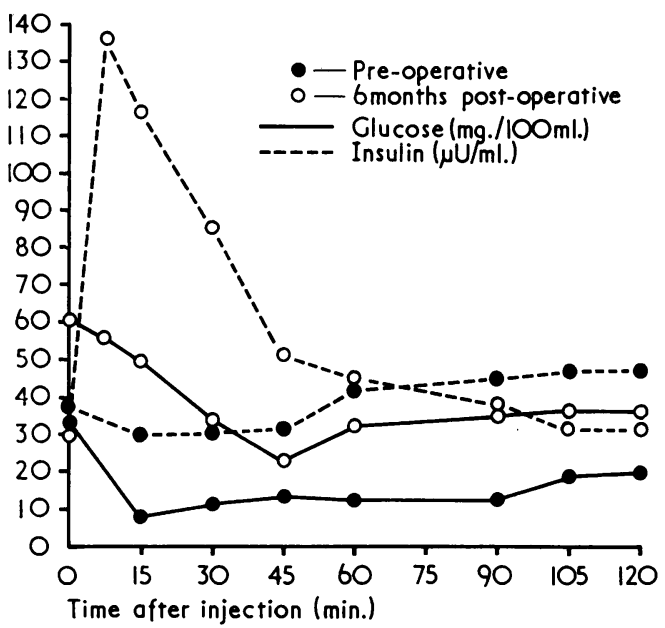

FIG.-Tolbutamide tests $(0.5 \mathrm{~g} . / \mathrm{kg}$. intravenously $)$. - Before operation; $\bigcirc 6$ months after operation.

limit of normal fasting levels in children in this agegroup is $25 \mu \mathrm{U} / \mathrm{ml}$. in our laboratory.) A glucose tolerance test (Table II) 2 weeks after admission showed a diabetic curve, but this result was felt to reflect the corticosteroid therapy and glucose supplements which had been required to control the hypoglycaemia. An intravenous tolbutamide test (Fig.) showed a pronounced hypoglycaemic response, the blood glucose of $11 \mathrm{mg} . / 100 \mathrm{ml}$. at 30 minutes rising to

TABLE II

Glucose Tolerance Tests

\begin{tabular}{|c|c|c|c|c|c|c|c|c|c|}
\hline & \multicolumn{8}{|c|}{ Time (hours) } & \multirow{2}{*}{$\begin{array}{l}\text { Dose of Glucose } \\
(\text { (g. } / \mathbf{k g} .)\end{array}$} \\
\hline & 0 & $\frac{1}{2}$ & 1 & $1 \frac{1}{2}$ & 2 & $2 \frac{1}{2}$ & 3 & 4 & \\
\hline $\begin{array}{l}\text { Pre-operative } \\
\text { Sugar (mg./100 ml.) }\end{array}$ & 84 & 276 & 186 & 117 & 76 & 88 & 68 & 61 & $1 \cdot 0$ \\
\hline $\begin{array}{l}1 \mathrm{mth} \text {. after operation } \\
\text { Sugar (mg./100 ml.) }\end{array}$ & 109 & 236 & 244 & 132 & 112 & 80 & 100 & 110 & $1 \cdot 0$ \\
\hline $\begin{array}{l}2 \text { mth. after operation } \\
\text { Glucose }(\mathrm{mg} . / 100 \mathrm{ml} .) \\
\text { Insulin }(\mu \mathrm{U} / \mathrm{ml} .) \\
\text { Growth hormone (ng./ml.) }\end{array}$ & $\begin{array}{r}102 \\
18 \\
13\end{array}$ & $\begin{array}{r}121 \\
220 \\
1\end{array}$ & $\begin{array}{r}72 \\
49 \\
1\end{array}$ & $\begin{array}{r}44 \\
18 \\
1\end{array}$ & $\begin{array}{r}100 \\
70 \\
2\end{array}$ & $\bar{z}$ & 二 & $\begin{array}{r}63 \\
6 \\
13\end{array}$ & $1 \cdot 75$ \\
\hline $\begin{array}{l}5 \text { mth. after operation } \\
\text { Glucose (mg./100 ml.) } \\
\text { Insulin }(\mu \mathrm{U} / \mathrm{ml} .)\end{array}$ & $\begin{array}{l}75 \\
34\end{array}$ & $\begin{array}{l}141 \\
212\end{array}$ & $\begin{array}{l}108 \\
198\end{array}$ & $\begin{array}{r}90 \\
150\end{array}$ & 二 & $\begin{array}{l}55 \\
28\end{array}$ & - & $\overline{-}$ & $1 \cdot 75$ \\
\hline $\begin{array}{l}7 \mathrm{mth} \text {. after operation } \\
\text { Glucose (mg./100 ml.) } \\
\text { Insulin }(\mu \mathrm{U} / \mathrm{ml} .)\end{array}$ & $\begin{array}{l}69 \\
24\end{array}$ & $\begin{array}{l}107 \\
180\end{array}$ & $\begin{array}{l}100 \\
159\end{array}$ & $\begin{array}{l}80 \\
91\end{array}$ & $\begin{array}{l}59 \\
32\end{array}$ & $\overline{-}$ & $\overline{-}$ & $=$ & $1 \cdot 75$ \\
\hline $\begin{array}{l}12 \text { mth. after operation } \\
\text { Glucose (mg./100 ml.) } \\
\text { Insulin }(\mu \mathrm{U} / \mathrm{ml} .) \\
\text { Growth hormone (ng./ml.) }\end{array}$ & $\begin{array}{l}63 \\
14 \\
15\end{array}$ & $\begin{array}{r}106 \\
58 \\
<1\end{array}$ & $\begin{array}{r}100 \\
82 \\
<1\end{array}$ & $\bar{z}$ & $\begin{array}{r}78 \\
43 \\
<1\end{array}$ & $\bar{z}$ & $\begin{array}{r}60 \\
14 \\
<1\end{array}$ & $\begin{array}{l}56 \\
17 \\
17\end{array}$ & $1 \cdot 75$ \\
\hline
\end{tabular}


only $18 \mathrm{mg} . / 100 \mathrm{ml}$. at 120 minutes. A slightly raised fasting plasma insulin level of $36 \mu \mathrm{U} / \mathrm{ml}$. was recorded, but the subsequent insulin response was within normal limits. Despite the absence of tolbutamide-induced hyperinsulinism, the clinical picture, together with increased random and fasting insulin levels, was felt to be sufficiently typical of pancreatic insulinoma to justify an exploratory laparotomy, which was performed by one of us (A.G.) 1 month after admission.

Operative findings and procedure. The laparotomy was performed through a right paramedian incision. A round, dark red tumour, $1 \mathrm{~cm}$. in diameter, was found in the pancreas at the junction of the body and the tail. An accessory spleen was noted.

Partial pancreatectomy and splenectomy were performed, leaving the head of the pancreas and the accessory spleen intact.

Pathology of pancreas (Dr. A. H. Cameron). The tail and body of the pancreas were approximately $13 \mathrm{~cm}$. in length; $3 \mathrm{~cm}$. from the amputated proximal end of the pancreas was a small round tumour $1 \cdot 1 \mathrm{~cm}$. in diameter. It was situated close to the splenic artery and vein on the upper border of the pancteas and had a well-defined margin. Its cut surface had a moist red colour. Slicing of the pancreas after fixation, at intervals of $0.4 \mathrm{~cm}$., showed no further tumour, but six lymph nodes, the largest measuring $1.0 \mathrm{~cm}$. in diameter.

Histology showed normal exocrine tissue of the pancreas, and the islets were of normal size and number. The lymph nodes showed oedema of the sinusoids. The tumour was an islet cell adenoma. There was no investing capsule, and in one area the tumour infiltrated adjacent glandular tissue. It consisted of anastomosing short irregular cords of somewhat polyhedral shape, the cords being separated by a rich network of blood-filled sinusoids. The tumour cells varied a little in appearance, the cytoplasm being unusually pale but eosinophilic in some areas. There was slight to moderate mitotic activity. Gomori's aldehyde fuchsin for $\beta$-cells was negative, though positive in surrounding islets. Bodian's method for $a$-cells showed a positive reaction in many of the cells of the tumour as well as in the surrounding normal islets.

The insulin activity of tissue from the tumour was three times that of an equal quantity of tissue from the surrounding normal pancreas.

Post-operative course and further follow-up. The immediate post-operative course was uneventful. Plasma insulin values fell promptly to normal. Transient hyperglycaemia and glycosuria, without acidosis, occurred and lasted for less than 24 hours. The pancreas continued at first to produce excessive insulin secretion after intravenous tolbutamide and oral glucose, suggesting either compensatory hypertrophy of the remaining islet tissue, or the presence of another insulinoma. Glucose tolerance tests have been per- formed at intervals, and the results are given in Table II. The glucose response has remained within normal limits but the insulin response, which was initially raised, has progressively returned to normal during a 12-month follow-up period. A tolbutamide test (Fig.) performed 6 months after operation again provoked a pronounced fall in the blood glucose levels, and surprisingly the insulin response was within the abnormal range (136 $\mu \mathrm{U} / \mathrm{ml}$. at $7 \frac{1}{2}$ minutes). However, no further episodes of hypoglycaemia have been recorded, and $x$-rays of the chest and bones have shown no evidence of metastases, so we do not consider that another insulinoma is present.

The hypoglycaemia produced evidence of cerebral damage which was initially severe, but her recovery has been better than was anticipated. Aphasia and left hemiparesis were apparent when she regained consciousness. For several months after pancreatectomy her behaviour was violent and aggressive, necessitating a period of in-patient care in hospital for the mentally subnormal. Treatment with chlorpromazine and anticonvulsants produced an improvement in her social response and she is now cared for at home. Intelligence testing (Wechsler Intelligence Scale for Children) performed 6 months after operation gave a value of 61, and 12 months after it was 67. Apart from slight dysarthria there are now no localizing neurological signs. Her behaviour has improved but she has not yet been able to adjust to ordinary school life.

\section{Discussion}

Incidence of insulinoma in childhood. We have reviewed the literature on this subject and found 34 published cases in children aged less than 15 years, not including our own case (Antony, Underwood, and Van Wyk, 1967; Bernheim et al., 1961a; Boley, Lin, and Schiffmann, 1960; Massachusetts General Hospital, 1962; Drash and Schultz, 1967; Garces, Drash, and Kenny, 1968; Géraud et al., 1966; Hartmann et al., 1960; Hurez et al., 1961; MacGillivray, Galloway, and Easton, 1958; McQuarrie, 1954; Rogers, 1960; Salinas et al., 1968; Sauls, 1968; Scholten and van der Vegt, 1960; Thomson and Welch, 1962; Watkins and Traylor, 1963).

Our inquiries to the heads of Paediatric Departments in the United Kingdom revealed four unpublished cases, details of which are given in the Appendix to this paper (S. H. Dave and T. R. Savage, 1962; J. W. Farquhar, 1967; F. P. Hudson, 1961; G. A. Neligan, 1963; personal communications).

A number of cases have been excluded for various reasons. When Boley et al. reviewed the literature in 1960, they found 15 examples of insulinoma and also gave details of 2 children aged 6 and 10 months in whom there was diagnostic 
doubt. One had severe liver disease which they thought contributed more to the child's death than a small islet cell adenoma; the other probably had islet cell hyperplasia. One of the cases described by François et al. (1962) died in the neonatal period, and at necropsy was found to have both islet hyperplasia and an adenoma. (This case had already been published in 1961 by Bernheim et al., 1961b.) A. D. Bain (1955, personal communication) gave us details of a baby aged 1 month in whom an islet cell tumour was found at necropsy. The baby had had convulsions, but hypoglycaemia was never recorded, and there was evidence of nephrosis, septicaemia, and pulmonary haemorrhage at necropsy. Ellis (1965) described a 14year-old girl who had an islet cell carcinoma which was non-functioning, and hypoglycaemia did not occur. There are reports (Underwood and Jacobs, 1963; Wermer, 1954) of insulinomas in children suffering from familial endocrine adenomatosis (the pluri-glandular syndrome). Burkinshaw, O'Brien, and Pendower (1967) described Cushing's syndrome in a 2-year-old boy with an islet cell tumour, but hyperinsulinism was not present. None of the cases mentioned above will be discussed further as they probably represent separate entities.

TABLE III

Age Incidence of Pancreatic Islet Cell Adenoma in Childhood

\begin{tabular}{l|c|c|c}
\hline Age (yr.) & $\begin{array}{c}\text { Cases Reviewed } \\
\text { by Boley } \text { et al. } \\
(1960)\end{array}$ & $\begin{array}{c}\text { Additional } \\
\text { Published and } \\
\text { Unpublished } \\
\text { Cases }\end{array}$ & Total \\
\hline$<1$ & 0 & 7 & 7 \\
$1-2$ & 0 & 2 & 2 \\
$2-4$ & 0 & 0 & 0 \\
$4-10$ & 9 & 9 & 14 \\
$10-15$ & 0 & 1 & 15 \\
Age not stated & 15 & 24 & 39 \\
\hline Total & 0 & 9 & 1 \\
\hline
\end{tabular}

Sex and age incidence. Analysis of the 39 children aged less than 15 years with functioning insulinomas showed 21 males and 14 females. (The sex was not stated in 4 cases.)

The ages of the children at the onset of symptoms, or at diagnosis if the former was not stated, are given in Table III. Boley et al. (1960) consider that, because of the rarity of islet cell adenoma in children aged less than 4 years, the age of onset of symptoms represents the most important diagnostic criterion. We have found no definite pattern of age incidence, and therefore cannot agree with this statement. It appears that the condition is more common in infancy than in childhood, though the numbers are small. We must emphasize, however, that hypoglycaemia is of frequent occurrence in infancy and an insulinoma is a rare cause in this age-group. On the other hand, though spontaneous hypoglycaemia is rare in the older child an insulinoma is a likely cause of this disturbance in a child aged more than 4 years.

Nature of tumour. A single adenoma was present in 33 cases. In each of the 3 cases described by S. H. Dave and T. R. Savage (1962, personal communication), Frank (1935), and Howard, Moss, and Rhoads (1950), 2 adenomas were present. 3 adenomas were present in each of the 3 children described by Drash and Schultz (1967); Géraud et al. (1966); and Wolf, Hare, and Riggs (1933).

Two of the children had malignant insulinomas (Hurez et al., 1961; Thomson and Welch, 1962).

Insulinomas occurred in all parts of the pancreas. The site was not stated in every case, but there were approximately twice as many tumours in the body and tail as in the head of the pancreas.

A histological distinction between $\alpha$ - and $\beta$ pancreatic islet cells is difficult, requiring special staining techniques which have not been used in most reported cases. Even when used these techniques may fail to give a clear indication of the cell type. Though $\beta$-cells are thought to be the site of insulin secretion, in our case $a$-cells predominated, and we can give no explanation of this. Though we have excluded cases of insulinoma associated with other endocrine adenomata or with the Zollinger-Ellison syndrome from this paper, a definite relation appears to exist between them. Insulinoma may represent one form of a spectrum of endocrine disease, as suggested by Underwood and Jacobs (1963) and Murray-Lyon et al. (1968).

Symptoms and signs. The presenting symptoms of insulinoma are the clinical manifestations of hypoglycaemia which occur usually in the morning before breakfast, or after periods of fasting or exercise. Boley et al. (1960) found that convulsions and episodes of unconsciousness were the most frequent symptoms, followed by drowsiness, behaviour changes, mental deterioration, and ataxia. Physical findings are generally absent and a delay of months or even years before diagnosis is not unusual.

An insulinoma discovered in the first weeks of life (Massachusetts General Hospital, 1962; J. W. Farquhar, 1967, personal communication; Garces 
et al., 1968; Salinas et al., 1968; Sauls, 1968; Scholten and van der Vegt, 1960) most frequently presents with convulsions or cyanotic attacks. Profuse sweating, pallor, and a shrill cry may also be observed. Characteristically the hypoglycaemia is very resistant to the usual therapeutic measures employed for neonatal hypoglycaemia, and the baby may progress rapidly to unconsciousness and death (Scholten and van der Vegt, 1960). Developmental retardation is common in these early cases, despite surgical removal of the tumour. Growth failure was noted in one child who had a remarkable growth spurt after subtotal pancreatectomy (Garces et al., 1968).

Biochemical diagnosis. Biochemical confirmation of a suspected insulinoma is difficult but has been made easier by the availability of insulin assays. Hyperinsulinism may be suggested by the presence of Whipple's triad (Whipple, 1944), i.e. symptoms which characteristically occur in the early morning before breakfast or after physical effort and which can be provoked by fasting, associated with blood sugar levels below $50 \mathrm{mg}$./ $100 \mathrm{ml}$., and relieved by the administration of sugar. However, in the younger child the presence of Whipple's triad does not distinguish insulinoma from other causes of hypoglycaemia, such as the idiopathic hypoglycaemia of infancy described by McQuarrie (1954), and islet hyperplasia.

The characteristic glucose tolerance curve of hyperinsulinism shows a low fasting level, and hypoglycaemia may occur again 3 or 4 hours after the load. The test in our patient was atypical due to corticosteroid therapy and a high glucose intake.

Excessive and prolonged hypoglycaemia after intravenous tolbutamide is a useful diagnostic pointer towards insulinoma in adults, and occurred in our case. However, many investigators (Antony et al., 1967; Cunningham, 1964; Di George and Chiowanich, 1962; Drash and Schultz, 1967; Erlich and Martin, 1967; Schotland, Kaplan, and Grumbach, 1967) have found the test less valuable in childhood. This is because similar results occur in children with hypoglycaemia from other causes, notably McQuarrie's idiopathic type, leucine-sensitivity, and islet cell hyperplasia.

Tolbutamide often produces a dramatic rise in plasma insulin levels when an insulinoma is present. The failure to show this in our patient before operation was disappointing, but others (Cunningham, 1964; Drash and Schultz, 1967; Garces et al., 1968; Marks and Rose, 1965) have had similar negative results. It is possible that we missed the peak plasma insulin level as this may occur within 5 minutes of the tolbutamide injection (Maingay et al., 1967). We consider, therefore, that the tolbutamide test is of limited usefulness in childhood.

Oral leucine (Antony et al., 1967; Di George and Auerbach, 1960; Garces et al., 1968; Marks and Rose, 1965) and intramuscular or intravenous glucagon (Garces et al., 1968; Marks and Rose, 1965) may produce hypoglycaemia in children with insulinomas and this test may give diagnostic help.

The detection of raised fasting plasma insulin levels is the most useful single diagnostic guide. However, multiple estimations may be required before a raised level is demonstrated (Marks and Rose, 1965), and in 2 cases raised plasma insulin levels were never found (Drash and Schultz, 1967; Garces et al., 1968). Grant (1967) found the normal range of fasting plasma insulin in children to vary from undetectable levels to $32 \mu \mathrm{U} / \mathrm{ml}$. (mean $=8 \mu \mathrm{U} / \mathrm{ml}$.). He showed that there was a progressive rise in fasting insulin levels with increasing age through childhood, but that children aged 11 to 15 years (range 7-32 $\mu \mathrm{U} / \mathrm{ml}$., mean $16 \mu \mathrm{U} / \mathrm{ml}$.) had significantly higher levels than adults (range $6-20 \mu \mathrm{U} / \mathrm{ml}$. mean $10 \mu \mathrm{U} / \mathrm{ml}$.).

Normal levels measured in the Institute of Child Health, Birmingham, lie within a similar range, with the upper limit of normal for the 11 to 15 years age-group being $25 \mu \mathrm{U} / \mathrm{ml}$.

We are unable to explain the high alkaline phosphatase level in our patient. There is no evidence of hyperparathyroidism, the tumour did not produce biliary obstruction, and there has been no evidence of metastases in the liver or bones. The alkaline phosphatase level returned to normal after subtotal pancreatectomy. We have found no reference to this phenomenon in the literature on insulinoma. A possible explanation is that alkaline phosphatase was being produced by the adenoma.

Treatment. When raised fasting plasma insulin levels are detected in an infant or child with resistant spontaneous hypoglycaemia, early surgical exploration should be undertaken. A thorough search should be made for an insulinoma in the pancreas itself and also in the sites where an ectopic pancreatic tumour may be found (Lancet, 1967), bearing in mind that more than one tumour may be present. A simple excision of the tumour may be sufficient, but subtotal pancreatectomy is the more usual procedure.

A problem arises when no obvious tumour is present. The results of 'blind' pancreatectomy in 
adults were analysed by Mengoli and Le Quesne (1967) who found a tumour in the excised distal pancreas in only 11 of 47 such cases. (In 24 cases a tumour was found at a subsequent operation performed for persisting symptoms.) The problem in children with hyperinsulinism is influenced by the alternative diagnosis of islet cell hyperplasia, for in these cases subtotal pancreatectomy is indicated if medical treatment has failed (Hamilton et al., 1967; Peters and Stanten, 1965). Moreover, the operation of subtotal pancreatectomy is technically simpler in children than in adults. Therefore, where hyperinsulinism has been shown in a child with resistant spontaneous hypoglycaemia, we suggest that a subtotal pancreatectomy be done if an insulinoma is not found.

The medical treatment of hypoglycaemia due to islet cell adenoma is ineffective, and the hypoglycaemia tends to become progressively more severe. Frequent carbohydrate feeds, and corticosteroid and ACTH therapy are of only temporary benefit (Boley et al., 1960). Diazoxide, a hyperglycaemic benzothiadiazine derivative, which inhibits insulin release from the islet cells, has been of use in the management of some adults with insulinomas, particularly to control hypoglycaemia from metastases (Ernesti et al., 1965; Marks, Rose, and Samols, 1965). Diazoxide was ineffective in the 3 infants described by Garces et al. (1968) and Salinas et al. (1968). The use of very large doses of diazoxide was successful in controlling the hypoglycaemia in a 10-year-old girl with microadenomatosis of the pancreas as part of the pluriglandular syndrome, but side-effects were troublesome (Lloyd, 1968). An antibiotic extracted from Streptomyces acromogenes, Streptozotocin, which damages the $\beta$-cells of the pancreatic islets in animals and produces diabetes mellitus, controlled the hypoglycaemic symptoms in an adult with a malignant islet cell tumour (Murray-Lyon et al., 1968). The tumour also secreted gastrin and glucagon and the production of these hormones was diminished by the drug. Further trials of treatment with this new drug are required. We conclude that medical treatment of insulinoma is indicated only to enable an accurate diagnosis to be made, or if immediate operation is contraindicated for some reason.

This contrasts with the more favourable results of diazoxide therapy for leucine sensitivity (Drash and Wolff, 1964; Bower, Rayner, and Stimmler, 1967), where the hypoglycaemia is due to leucineinduced hyperinsulinism. In this condition the natural history is towards gradual improvement so that medical therapy is justifiable.
Dietary measures and corticosteroid or ACTH treatment will usually control the idiopathic hypoglycaemia of childhood (McQuarrie, 1954), which also has a tendency to natural recovery.

In small infants, therefore, where diagnosis of the exact cause of hypoglycaemia may be difficult, we suggest that dietary measures, steroid or ACTH, and diazoxide therapy should be given a trial, and early surgical exploration should be made if these fail.

Prognosis. There is no long-term series of follow-up studies of insulinoma treated in childhood. A study of Whipple's 6 patients 25 years after the original treatment gives a depressing picture of the condition in adults (Markowitz, Slanetz, and Frantz, 1961). Only 1 patient was completely well. Later complications included psychiatric illnesses, peptic ulceration, diabetes, recurrent insulinomas, or parathyroid adenomata. Two patients had died, one from a bleeding peptic ulcer and the other after operation for recurrent insulinomas. Four of these patients might now be considered to be examples of the pluriglandular syndrome.

\section{TABLE IV \\ Outcome in 37 Children with Benign Islet Cell Adenoma}

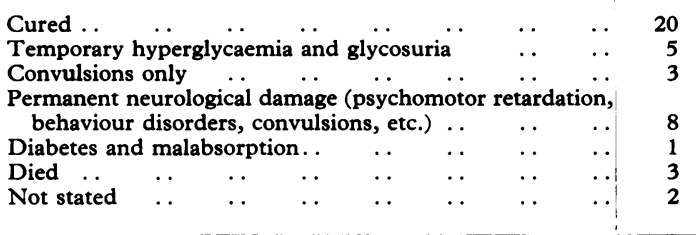

Table IV summarizes the results in 37 children who had benign insulinomas. The periods of follow-up varied from a few months to 17 years. Complete recovery occurred in more than half, though 5 had transient post-operative hyperglycaemia and glycosuria. The most prominent sequelae were neurological, consisting of psychomotor retardation, convulsions, personality changes, and behaviour disorders. Convulsions were the only neurological sequelae in 3 children. Only 1 child had pancreatic malabsorption and diabetes requiring long-term insulin therapy. Of the 3 deaths, 2 occurred in children with multiple adenomata (Frank, 1935; Wolf et al., 1933) and one was in a neonate (Scholten and van der Vegt, 1960).

The two children with malignant tumours were both well at 6 months (Hurez et al., 1961) and 6 years (Thomson and Welch, 1962) after operation. 


\section{Summary}

The case of a 12-year-old girl with an insulinoma is described in detail, and short accounts are given of 4 other children presenting with this condition in the United Kingdom during the past 10 years. The literature has been reviewed, and the sex and age incidence, presenting symptoms and signs, and the nature of the tumour in the 39 children aged less than 15 years are discussed. There have been 9 children aged less than 4 years with insulinomas and, contrary to previous reports, the condition appears to be at least as common in this age-group as in older children.

Biochemically, the most useful guide in diagnosis is the detection of raised fasting plasma insulin levels. The therapeutic approach is outlined with reference to the diagnostic problems peculiar to the younger child and despite hypoglycaemic episodes and the risk of brain damage, more than $50 \%$ of children with insulinomas made a complete recovery after treatment.

We wish to thank Professor D. V. Hubble for permission to report his case and for the helpful advice and encouragement he gave us in the preparation of this paper; Drs. A. D. Bain, F. P. Hudson, T. R. Savage, G. A. Neligan, and J. W. Farquhar for giving us details of their patients; G. A. Brown and J. Williams for assaying the plasma insulin levels and the insulin activity of the pancreatic tissue; Dr. A. H. Cameron for the histological studies; and Miss $\mathrm{H}$. Newton for performing the IQ tests.

\section{Appendix}

Brief details of the four unpublished cases of insulinoma in children are given below. We are grateful to the paediatricians concerned for allowing us to include their cases in this review.

Case 1 (F. P. Hudson, Liverpool). A 9-year-old girl presented in 1961 with a sudden illness in which she developed diplopia, fatigue, and then unconsciousness. She was admitted to hospital and recovered quickly and spontaneously. Over the next 2 months she had several more episodes suggestive of grand mal epilepsy. Finally she was admitted to hospital in coma and hypoglycaemia (blood sugar $40 \mathrm{mg}$./100 ml.) was diagnosed. The hypoglycaemia proved resistant to therapy, a high protein diet and intravenous glucose producing only temporary improvement. A period of 4 weeks ensued during which she was drowsy or comatose and had several convulsions. During this time the effect of fasting was studied and she became hypoglycaemic and unconscious within 4 hours.

Further investigations were considered inadvisable, and at laparotomy (Miss I. Forshall) an islet cell adenoma was removed from the head of the pancreas. Assay of an extract from the tumour revealed a high insulinlike activity. The post-operative course was satis- factory, and the child's recovery complete, despite the prolonged and severe hypoglycaemia. She was making normal progress at school 6 years after the operation.

Case 2 (S. H. Dave and T. R. Savage, Oldchurch Hospital, Romford). This case was shown at a meeting of the Section of Paediatrics at the Royal Society of Medicine on March 22, 1963.

A 10-year-old girl was admitted to hospital in 1962 in hypoglycaemic coma (blood sugar $60 \mathrm{mg} . / 100 \mathrm{ml}$.) and responded to intravenous glucose. For 2 years she had been having episodes, usually just before her dinner, of hunger, inability to concentrate, sweating, clumsiness, and drowsiness. Three days before admission she had been unconscious at home for a few hours.

Investigations showed fasting hypoglycaemia associated with raised fasting plasma insulin levels (121, $52,50 \mu \mathrm{U} / \mathrm{ml}$.). There was a prolonged hypoglycaemic response to intravenous tolbutamide (blood glucose $25 \mathrm{mg} . / 100 \mathrm{ml}$. at $20,30,60,90$, and 120 minutes) associated with a high plasma insulin response (maximum $327 \mu \mathrm{U} / \mathrm{ml}$. at 20 minutes). Leucine sensitivity was present. A glucose tolerance test showed a low peak of $65 \mathrm{mg} . / 100 \mathrm{ml}$. at 30 minutes, followed by a fall to hypoglycaemic levels $(20 \mathrm{mg} . / 100 \mathrm{ml}$.) at 2 hours. At laparotomy (Mr. E. B. Whittingham) two islet cell tumours were removed from the tail of the pancreas. Recovery remained complete during $2 \frac{1}{2}$ years of followup. No hypoglycaemic brain damage occurred.

Case 3 (G. A. Neligan, Newcastle). This 14-year-old boy was first admitted to hospital in Hartlepool by Dr. R. G. Welch in 1963, with a 2-month history of attacks of weakness and incoordination of his legs. For 1 month he had also had attacks of slurred speech, hallucinations, and possibly loss of consciousness. These attacks usually occurred before breakfast and during the midmorning and would be cured by a sweet drink. Hypoglycaemia was diagnosed and he was referred to Newcastle. In hospital there he had several attacks of aggressive, 'drunken' behaviour in which sweating was observed. Investigations included a 24-hour fast, after which the blood sugar was $29 \mathrm{mg}$. $/ 100 \mathrm{ml}$. Intramuscular glucagon produced an initial rise in blood sugar, followed by hypoglycaemia at $2 \frac{1}{2}$ hours after the injection.

At laparatomy (Professor A. G. R. Lowdon) a tumour $1 \mathrm{~cm}$. in diameter was found on the posterior surface of the body of the pancreas, after a long search. The tumour, an islet cell adenoma, was removed, and the child made a complete recovery. He was symptomfree when reviewed 6 months after the operation by Dr. Welch, and the fasting blood sugar level was normal.

Case 4 (J. W. Farquhar, Edinburgh). This baby boy presented in 1967 with hypoglycaemic convulsions at the age of 3 days. These occurred frequently for 3 weeks and prednisolone was given. Motor retardation was obvious, and further convulsions occurred with 
normal blood glucose levels. When the steroid was withdrawn hypoglycaemic incidents recurred.

Investigations included blood glucose levels below $10 \mathrm{mg}$. $/ 100 \mathrm{ml}$. during convulsions; and a fasting plasma insulin level of $65 \mu \mathrm{U} / \mathrm{ml}$. The response to a glucose load was small but not otherwise abnormal. Muscle and liver biopsies were unrevealing and the pancreas was macroscopically normal at laparotomy. A distal pancreatectomy was done and an islet cell adenoma approximately $1 \times 0.5 \times 0.4 \mathrm{~cm}$. was found on examination of the specimen.

Hypoglycaemia did not recur after operation, but phenobarbitone was required to control convulsions which were assumed to be due to the previous hypoglycaemic brain damage.

\section{REFERENCES}

Antony, G. J., Underwood, L. E., and Van Wyk, J. J. (1967). Studies in hypoglycemia of infancy and childhood. Amer. f. Dis. Child., 114, 345.

Bernheim, M., François, R., Sacrez, R., Mallet Guy, P., Feroldi, J., Germain, D., Sherrer, M., Ruiton-Ugliengo, Mme., and Pradon, M. (1961a). Hypoglycémie par adénome pancréatique chez une fillette de 8 ans. Intervention. Guérison. Pédiatrie, 16, 339.

_, Larbre, F., François, R., Gilly, R., and Pradon, M. (1961b). Hypoglycémie mortelle par adenome des ilots de Langerhans du pancréas chez le nouveau-né. ibid., 16, 631 .

Boley, S. J., Lin, J., and Schiffmann, A. (1960). Functioning pancreatic adenomas in infants and children. Surgery, 48, 592.

Bower, B. D., Rayner, P. H. W., and Stimmler, L. (1967). Leucinesensitive hypoglycaemia treated with diazoxide. Arch. Dis. Child., 42, 410.

Burkinshaw, J. H., O'Brien, D., and Pendower, J. E. H. (1967). Cushing's syndrome associated with an islet-cell tumour of the pancreas in a boy aged 2 years. ibid., 42, 525 .

Cunningham, G. C., Jr. (1964). Tolbutamide tolerance in hypoglycemic children. Amer. F. Dis. Child., 107, 417.

Di George, A. M., and Auerbach, V. H. (1960). Leucine-induced hypoglycemia. A review and speculations. Amer. f. med. Sci., 240, 792.

- and Chiowanich, P. (1962). The intravenous tolbutamide response test in infants and children. A preliminary report. Diabetes, 11, Suppl. 135.

Drash, A., and Schultz, R. (1967). Islet cell adenoma in childhood: report of a case. Pediatrics, $39,59$.

- and Wolf, F. (1964). Drug therapy in leucine-sensitive hypoglycemia. Metabolism, 13, 487.

Ellis, H. (1965). Malignant nonfunctioning islet cell tumour of the pancreas in a 14-year-old girl. Proc. roy. Soc. Med., 58, 432.

Erlich, R. M., and Martin, J. M. (1967). Tolbutamide tolerance test and plasma-insulin response in children with idiopathic hypoglycemia. F. Pediat., 71, 485.

Ernesti, M., Mitchell, M. L., Raben, M. S., and Gilboa, Y. (1965). Control of hypoglycaemia with diazoxide and human growth hormone. Lancet, 1, 628.

Floyd, J. C., Jr., Fajans, S. S., Knopf, R. F., and Conn, J. W. (1964). Plasma insulin in organic hyperinsulinism: comparative effects of tolbutamide, leucine and glucose. $f$. clin. Endocr. 24, 747.

François, R., Pradon, M., Sherrer, M., and Ruiton-Ugliengo, A. (1962). Hypoglycemia due to pancreatic islet-cell adenoma. f. Pediat., 60, 721.

Frank, H. (1935). Letale Spontanhypoglykämie. Munch. med. Wschr., 82, 1829.

Garces, L. Y., Drash, A., and Kenny, F. M. (1968). Islet cell tumour in the neonate. Studies in carbohydrate metabolism and therapeutic response. Pediatrics, 41, 789.

Géraud, J., Pasquié, M., Rascol, A., Benazet, J., and Juskiewenski, S. (1966). Adénomes langerhansiens hypoglycémiants chez un enfant de 12 ans. Ann. Chir. infant., 7, 39.

Grant, D. B. (1967). Fasting serum insulin levels in childhood. Arch. Dis. Childh., 42, 375.
Hamilton, J. P., Baker, L., Kaye, R., and Koop, C. E. (1967). Subtotal pancreatectomy in the management of severe persistent idiopathic hypoglycemia in children. Pediatrics, 39, 49.

Hartmann, A. F., Sr., Wohltmann, H. J., Holowach, J., and Caldwell, B. M. (1960). Studies in hypoglycemia. F. Pediat., 56, 211

Howard, J. M., Moss, N. H., and Rhoads, J. E. (1950). Hyperinsulinism and islet cell tumors of the pancreas with 398 recorded tumors. Int. Abstr. Surg., 90, 417.

Hurez, A., Bedouelle, J., Debray, H., Le Bras, A., and Hallé, B. (1961). Carcinome langerhansien avec manifestations hypoglycémiques sévères chez un enfant de 9 ans-pancréatectomie partielle. Arch. franç. Pédiat., 18, 625.

Lancet (1967). 'Blind' pancreatectomy. Annotation, 2, 1404.

Lloyd, J. (1968). Pluriglandular syndrome with hyperinsulinism. Cardiomegaly as a possible complication of diazoxide therapy. Proc. roy. Soc. med., 61, 1257.

MacGillivray, P. C., Galloway, J. P., and Easton, H. G. (1958). Islet-cell tumour of the pancreas. Report of a case in a child aged 7 years. Brit. F. Surg., 46, 180.

McQuarrie, I. (1954). Idiopathic spontaneously occurring hypoglycemia in infants. Amer. F. Dis. Child., 87, 399.

Maingay, D., de Ruyter, H. A., Touber, J. L., Croughs, R. J. M., Schopman, W., and Lequin, R. M. (1967). Rapid rise of insulin concentration in the plasma after intravenous administration of sodium tolbutamide. Lancet, 1, 361.

Markowitz, A. M., Slanetz, C. A., Jr., and Frantz, V. K. (1961). Functioning islet cell tumours of the pancreas. 25-year follow up. Ann. Surg., 154, 877.

Marks, V., and Rose, F. C. (1965). Hypoglycaemia. Blackwell, Oxford.

- - $\longrightarrow$ and Samols, E. (1965). Hyperinsulinism due to metastasizing insulinoma: treatment with diazoxide. Proc. roy. Soc. Med., 58, 577.

Massachusetts General Hospital (1962). Case records (38-1962). New Engl. F. Med., 266, 1269.

Mengoli, L., and Le Quesne, L. P. (1967). Blind pancreatic resection for suspected insulinoma: a review of the problem. Brit. F. Surg., 54, 749.

Murray-Lyon, I. M., Eddleston, A. L. W. F., Williams, R., Brown, M., Hogbin, B. M., Bennett, A., Edwards, J. C., and Taylor, K. W. (1968). Treatment of multiple-hormone-producing malignant islet-cell tumour with streptozotocin. Lancet, 2 895.

Peters, H. E., Jr., and Stanten, E. (1965). Pancreatic resection for hypoglycemia in children. Amer. F. Surg., 110, 198.

Rogers, F. A. (1960). Islet cell tumours of the pancreas and hyperinsulinism. ibid., 99, 268.

Salinas, E. D., Jr., Mangurten, H. H., Roberts, S. S., Simon, W. H., and Cornblath, M. (1968). Functioning islet cell adenoma in the newborn. Report of a case with failure of diazoxide. Pediatrics, 41, 646.

Sauls, H. S., Jr. Personal communication to Salinas et al., 1968

Scholten, H. G., and van der Vegt, J. H. (1960). Functionerend eilandceladenoom van het pancreas bij een pasgeborene. Maandschr. Kindergeneesk., 28, 140.

Schotland, M. G., Kaplan, S. L., and Grumbach, M. M. (1967) The tolbutamide tolerance test in the evaluation of childhood hypoglycemia. Pediatrics, 39, 838.

Thomson, S., and Welch, K. J. (1962). Surgery of the pancreas. In Pediatric Surgery, Vol. I, p. 631. Ed. by C. D. Benson, W. T. Mustard, M. M. Ravitch, W. H. Snyder, and K. J. Welch. Year Book Medical Publishers, Chicago.

Underwood, L. E., and Jacobs, N. M. (1963). Familial endocrine adenomatosis. A family with hyperinsulinism as the predominant manifestation. Amer. F. Dis. Child., 106, 218.

Watkins, D. H., and Traylor, F. A. (1963). Islet-cell adenoma as a cause of juvenile hyperinsulinism in a 4-year-old boy. $\mathcal{F}$. Amer. med. Ass., $185,139$.

Wermer, P. (1954). Genetic aspects of adenomatosis of endocrine glands. Amer. F. Med., 16, 363.

Whipple, A. O. (1944). Hyperinsulinism in relation to pancreatic tumors. Surgery, 16, 289.

Wolf, A., Hare, C. C., and Riggs, H. W. (1933). Neurological manifestations in two patients with spontaneous hypoglycemia. Bull. neurol. Inst. N.Y., 3, 232.

Correspondence to Dr. Jillian R. Mann, Children's Hospital, Ladywood Middleway, Birmingham, 16. 